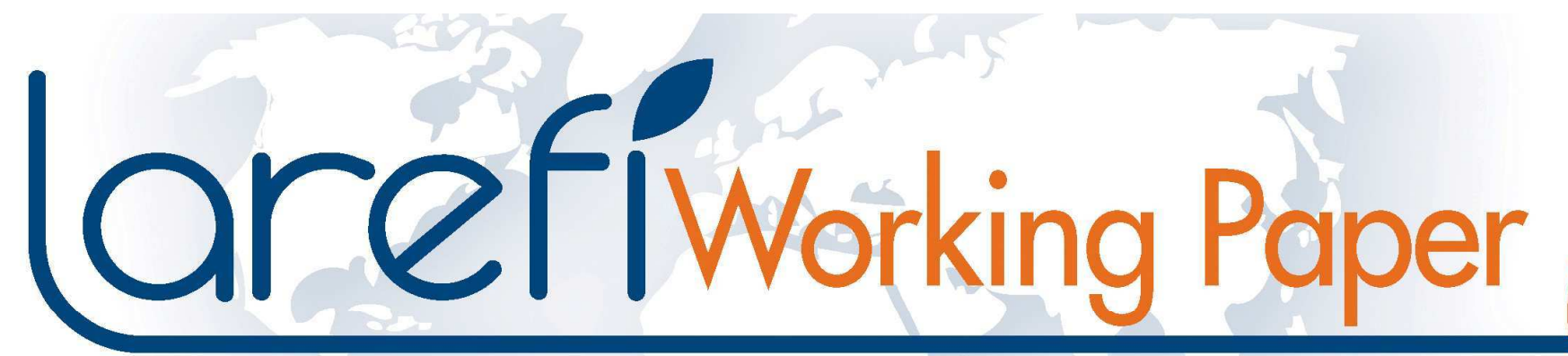

LABORATOIRE D’ANALYSE ET DE RECHERCHE EN ÉCONOMIE ET FinANCE INTERNATIONALES

\title{
Microcredit: an answer to the gender problem in funding?
}

\author{
Sophie Brana
}

LAREFI Working Paper N²010-08

2010

http://lare-efi.u-bordeaux4.fr

\section{LAREFI}

Université Montesquieu-Bordeaux IV

Bâtiment Recherche Economie $-1^{\mathrm{er}}$ étage

Avenue Léon Duguit - 33608 Pessac 


\section{LAREFI - LABORATOIRE D'ANALYSE ET DE RECHERCHE EN ECONOMIE ET FINANCES INTERNATIONALES}

\section{AUTHORS}

Sophie Brana, LAREFI, Université Montesquieu Bordeaux IV

\section{NOTICES}

LAREFI Working Papers contain preliminary material and research results. They have been peer reviewed. They are circulated in order to stimulate discussion and critical comment; any opinions expressed are only those of the author(s).

Copyright LAREFI. All rights reserved. Sections of this material may be reproduced for personal and not-for-profit use without the express written permission of but with acknowledgment to LAREFI. To reproduce the material contained herein for profit or commercial use requires express written permission. To obtain permission, contact LAREFI at cyril.mesmer@u-bordeaux4.fr. 


\section{Sommaire}

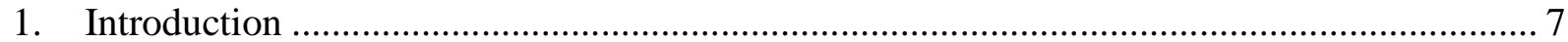

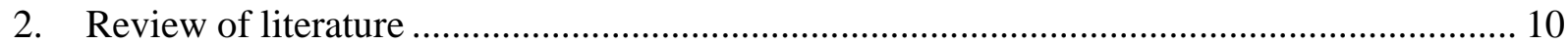

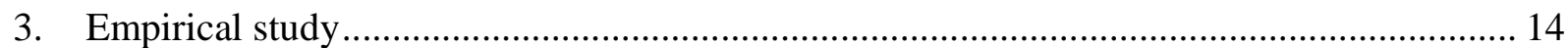

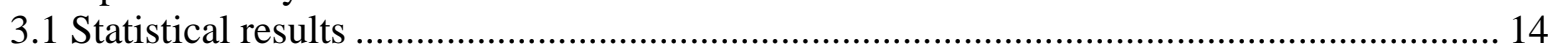

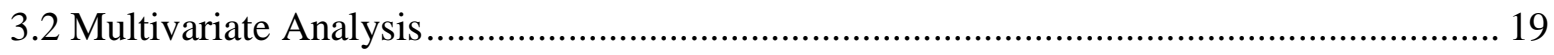

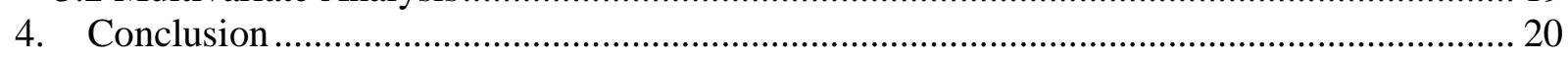




\section{List of table}

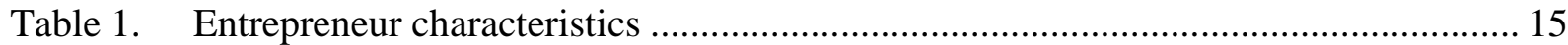

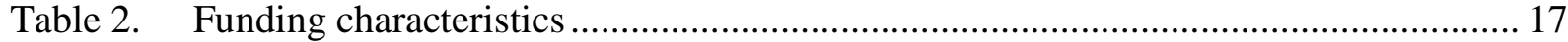

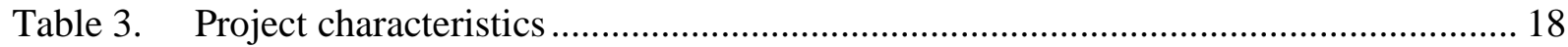

Table 4. Fixed-effects (within) regression: key factors when determining the amount of the

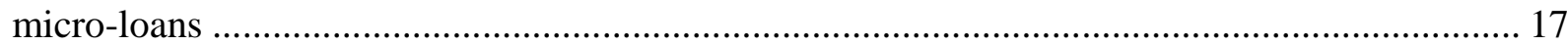

Table 5. Fixed-effects (within) regression: key factors when determining the amount of the

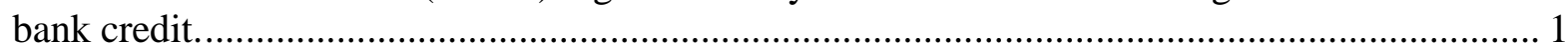




\begin{abstract}
Microfinance institutions (MFIs) target poor people, excluded from the banking system. By giving them starting capital, they should thus enable a greater number of women to create their own business, but also in sectors traditionally reserved for men due to the initial capital they require. Our study covers a portfolio of 3,640 microcredits in France over the 2000-2006 period. It identifies microfinance institutions' client profiles, brings to light the men/women differences and compares them to a wider sample of entrepreneurs. We show that the men/women gap found amongst company creators is maintained amongst clients of MFIs. We also demonstrate that the gender criterion is a decisive factor of the amount of the microcredit when compared to the borrower and firm profile. To a certain extent, MFI thus reproduce gender inequalities.
\end{abstract}

Keywords: Microcredit, Gender, Entrepreneurship, Small business.

JEL classification: G21, J16, L26, M13. 


\section{Introduction}

Microfinance ambitions in industrialized countries slightly differ from the well-known traditional objectives in developing countries. Microcredits are very small loans (less than $40 \%$ of the income per capita) granted to people totally or partially excluded from the banking system. In developing countries, the aim of microcredit is to reduce poverty, promote self-employment and improve the empowerment of socially excluded persons, women in particular. In industrialized countries, the goal is first of all to reduce poverty by encouraging self-employment. Microcredit thus answers two types of need. On the one hand, it enables people excluded from the banking system to create their own business, on the other it provides extra funding to entrepreneurs by creating a leverage effect with respect to bank credit.

Women should be particularly concerned by microcredit for two reasons. Firstly, they are more likely to be affected by unemployment and poverty. For example in France, the unemployment rate for women in 2007 was $8.5 \%$, as opposed to $7.4 \%$ for men $^{1}$. The part-time employment rate is $29.2 \%$, as opposed to $3.7 \%$ for men. Women represent the majority of non-working people, of long-term unemployed, of beneficiaries of welfare benefits, or of single parent families. They are therefore particularly vulnerable to the risk of poverty ${ }^{2}$. Secondly, women are also more vulnerable to financial exclusion, partial or total, especially women Entrepreneurs. Although women represent $47 \%$ of the French working population, in 2006 they accounted for only $30 \%$ of nascent entrepreneurs. Women entrepreneurs, on average, start their business with less capital (Insee, Sine survey 2006). This may explain why they face greater difficulties obtaining bank loans and funding their projects. Woman

\footnotetext{
${ }^{1}$ In France, 31\% of microcredit borrowers are unemployed people.

${ }^{2}$ For a review of gender inequalities in the risks of poverty and social exclusion in 30 European countries, see European Commission (2006).
} 
entrepreneurs cite access to finance as the most significant constraint affecting their business (Underwood 2006).

Microfinance institutions (MFIs) target more specifically poor people, excluded from the banking system. By offering start-up funding, they should encourage more women to create their own business, but also to create their business in sectors that are traditionally male-focused due to the initial capital they require. Does microfinance enable women to avoid financial constraints in industrialized countries? Does Microfinance really help women in terms of entrepreneurship?

The question of the link between microcredit and gender has given rise to an abundant literature in developing countries, but not in the industrialized economies ${ }^{3}$. In developing countries, the debate has focused on the impact of microfinance on gender equality or empowerment of women. According to Mayoux (2007), microfinance programs, by helping women to generate an income, trigger a virtuous circle of economic empowerment, increased well-being for women and their family, and on a wider scale increased political and social power for women.

Several studies, however, have qualified this positive view. Firstly, social and cultural inertia incites one to mitigate the impact of microfinance. As pointed out by Guérin and Palier (2006), whatever the quality and availability of microfinance, the road to equality is long and, even if microcredit can contribute to it, it does so only marginally. Many microfinance institutions target women primarily because they have higher repayment rates than men, their families get more benefit from their extra income, and because loan groups work better with them. It seems, however, that of 213 institutions reported by the "Microbanking Bulletin", the highest percentage of female clients is to be found in the most recent institutions. Conversely, the more mature institutions - banks, non-bank financial institutions, profit-making institutions, large scale institutions - tend to focus on the less poor of the

\footnotetext{
${ }^{3}$ To our knowledge, the only study is that of T. Underwood (2006) for the European Microfinance Network.
} 
poor and on small businesses. These large, profit-making organizations are less likely to reach women (Cheston 2007). In fact women, because they offer fewer collaterals than men and have access to smaller funds, are limited to so-called "feminine" occupations, not very capitalistic, often part-time, from home and generating little profit (Guérin, Palier 2006; D’espallier et al. 2010). The possibilities of economic empowerment and of rising above their social status remain limited. Moreover, Goes and Gupta (1996), for Bangladesh, have demonstrated that in many cases, women do not really control the use of funds that they have obtained. Indeed, because women have easier access to microcredit, men use them to get funds. For Fernando (2006), microcredit increases the responsibilities weighing on women, but not their real power, and it does not always make them less vulnerable to domestic violence.

Studies about women and microfinance in industrialized countries are scarce. In 2005 the European microfinance network (see T. Underwood 2006) launched the first statistical survey in order to determine to what extent European women were accessing microloans. The data from thirty microlenders over the period 2002-2004 indicates that 39\% of microloans were disbursed to women, above the $30 \%$ female entrepreneurship level in Europe. But despite a great potential to meet women's financing needs, the lending rate in Europe remains low compared to other countries.

\section{In order to go further, we have launched a data collection exercise for}

French IMF's portfolio. More precisely, our study covers all the microcredits granted over the 2000-2006 period in Aquitaine, the $6^{\text {th }}$ largest region in France, by the 12 microfinance institutions active in that region, including a portfolio of 3,640 microcredits. The aim of this study is to identify the profile of these microfinance institution clients, to reveal the differences between men and women and to compare them to the larger sample of entrepreneurs (using the French Institute for statistics database Insee). We will then check if the "gender" criterion weighs in on the characteristics of the loan. Do MFls 
reduce the obstacles women face with their projects or on the contrary, do they merely reproduce these inequalities?

The plan of the article is as follows. The following section presents a brief review of empirical literature on the relationship between gender, entrepreneurship and funding. Section 3 is devoted to an empirical analysis, with univariate and multivariate tests of differences in male and female use of microfinance. Finally, section 4 presents some concluding remarks and recommendations.

\section{Review of literature}

In industrialized countries, literature has focused on women and entrepreneurship or selfemployment, particularly in the United States, in Canada or in Great Britain. Anderson, Carter and Shaw (2001) thus list over 400 academic articles on women entrepreneurs. These studies reveal major differences between firms created by men and those created by women. They show that, compared to men, women start their own business with less financial capital, less experience and fewer resources in terms of human and social capital. This causes many women to set up under-funded businesses, which can have a negative impact on their long term performance. Thus the men/women differences are felt both with the structure (size of the firm, business sector) and with the profits. The performance outcomes (profitability, durability) of firms managed by women are generally lower ${ }^{4}$. But the impact of gender on economic performance has led to a great deal of controversy. Today however, a consensus seems to arise on the fact that if a number of variables can be controlled (business sector, starting resources, age of business, risk), men and women's performances will be similar (Watson 2002; Watson and Robinson 2003; Johnsen and McMahon 2005).

The most important research work has focused on the issue of gender and finance (Anderson, Carter and Shaw 2001), even if few systemic studies exist (De Bruin et al. 2007). Women experience

\footnotetext{
${ }^{4}$ In France, the durability rate for three year old firms is $70.4 \%$ for firms created by men and $67.7 \%$ for firms created by women.
} 
more difficulties than men to raise start-up and recurrent finance. Whatever the sector or area, women start their business with less capital than do men, while business survival is found to be positively related to the amount of start-up capital, other factors held constant ${ }^{5}$. Moreover in surveys, women generally declare that they are or have been discriminated against by banks. The general feeling is that banks are reluctant to give them credit. There are three main types of explanation put forward for this.

According to certain authors, women are discriminated against in terms of credit supply not because of their sex, but because of the less favourable characteristics of their project. Coleman (2000) argue that businesses managed by women are less attractive to banks because they are small and considered to be more risky. Banks prefer financing larger projects that are already established, a point that favours men. As a result of this adverse selection, the average quality of the women business decreases, causing a self-reinforcing discrimination mechanism (Scalera, Zazzaro, 2001). Riding and Swift (1990) compared the experience of men and women entrepreneurs in their relationship with financial institutions over a given period. They show that the financial conditions are less favourable to women, but that businesses managed by women are both younger and smaller than those managed by men, and have weaker economic growth. Banking conditions would therefore be the result of rational banking behaviour when faced with riskier projects. It seems women also experience greater difficulty in offering collaterals. As they are more likely to be working part-time or earning less than men, women find it more difficult to accumulate personal savings (Marlow and Patton 2005). Thus for both these reasons, lack of personal funds puts them at a disadvantage when creating their business. Their personal contribution is limited and such a small capital cannot be used as collateral to strengthen the loan relationship. Work experience before starting a business is therefore crucial to accumulate financial capital, but also human capital and to build up a network. Whereas Robb and Wolken (2002), or Cole and Mehran (2009) for the United States demonstrate that when the firm and owner characteristics are

5 See for example Boden and Nucci (2000). 
taken into account, women have equal access to credit $^{6}$, other studies found that structural dissimilarities cannot account for all the gender differences in financing patterns ${ }^{7}$.

Other authors focused on demand size risk and debt aversion (Bird and Brush 2002). It seems women are less encouraged to start businesses with high growth rates that require significant investments (financial and human) and prefer to avoid debt, which would explain why they do not apply for bank credits so much. Women start their business to assure their own employment rather than to develop it. For Danes et al. (2007), because they give priorities to their families and because they are in charge of educating their children, they opt for smaller organizational structures that are easier to manage. Barbato and DeMartino (2003) compare male and female entrepreneurs who are similar in terms of business education. They showed that women are less motivated by wealth creation and career advancement and that they prefer a career that give them flexibility and allowed them to manage their family obligations. Moreover, the 2006 Global entrepreneurship monitor survey (cf. Allen et al. 2007) shows that fewer women than men believe they have the required knowledge and skills to start their own business (32.9\% of women against $46.3 \%$ of Men in High income countries). Women have less selfconfidence. Whatever their reason for starting a business, they consider themselves and the entrepreneurial environment less favourably than men, which is a key point when explaining the smaller number of women in this area (Langowitz and Minniti 2007). They are also more risk averse than men (Watson and Robinson 2003), which leads them to ask for smaller loans ${ }^{8}$.

Thus, faced with similar projects, it seems difficult to pinpoint real discrimination by banks, although studies are contradictory. It seems discrimination regarding credit supply is not systematic but low (6\% out of the 325 cases studied by Carter et al. 2007) and not deliberate. However, as Marlow and Patton (2005) observed, studies tend to focus on the results rather than on the process. Even though access to credit is identical for similar projects and profiles, a number of studies show that relationships

\footnotetext{
${ }^{6}$ However, these studies rely upon the same database for the U.S. (the SSBFs).

${ }^{7}$ see Carter and Shaw 2006 for a survey.

${ }^{8}$ See Croson and Gneezy (2009) for a survey of gender differences in preferences.
} 
with lenders are more difficult for women. Firstly, women are generally less satisfied with their banking relationship than men (Buttner and Rosen 1988, Hayen et al. 2007). Secondly, Carter et al. (2007) show that the trust relationship, an important aspect of the bank loan relationship, is not the same for men and women. Banks will require women to give proof of their knowledge on starting a business and of its different implications. Men on the other hand, are asked to demonstrate their social stability, by being married for example. Fay and Williams (1993) mailed to loan officers of major banks the files of people asking for loans where the only difference was the level of education or gender. They demonstrate that among people with higher school education, women are less likely than men to obtain a loan. For people with a university education, the chances are the same but the education variable will play a more important role for women. They come to the conclusion that the feeling women have of being discriminated against when asking for start up capital is grounded, but that this discrimination is probably unconscious and cultural, thus making it more difficult to change. Buttner and Rosen (1998), after surveying 106 bank loan officers, show that the characteristics associated with successful entrepreneurs are attributed to men more often than to women. Sexual stereotypes can therefore have an influence on the banking relationship in general. It seems also that women are asked more collaterals than men as well as a higher interest rate (Coleman, 2000). Riding and Swift (1990) created a witness group made up of firms managed by men, with identical characteristics in terms of age, size, business sector, growth rate and organization as those managed by women. They show that once these variables are controlled, there remains a significant statistical difference linked to gender. Women are asked for increased collateral to obtain a credit line. Bellucci et al. (2010) confirm for Italy that female business owners are significantly more likely to pledge collateral and also face significantly stricter credit limits. They conclude that they results are consistent with the taste-based discrimination theory. Finally, Muravyev et al. (2009) explore gender discrimination against entrepreneurs in 34 European countries. Their results provide some support for the hypothesis of discrimination against female entrepreneurs, 
who are less likely to obtain a bank loan and are charged higher interest rates, compared to male managed counterparts.

In industrialized countries, microfinance, because it provides funding and own funds to people, particularly to women who do not have any, may help to avoid some banking exclusion. It may also encourage access to bank credit and to more ambitious projects.

\section{Empirical study}

Our research covers the activity of all microfinance institutions in Aquitaine. Over the 2000-2006 period, 12 institutions gave just under 4,000 micro-loans amounting to a total of 18.7 million euros. We created a database using the client portfolios of these institutions. The complete data concerns 3,640 microcredit files, for a total of 17 million euros $(2,381 \text { men and 1,259 women })^{9}$. The advantage of this study is that it covers the almost exhaustive supply (over $90 \%$ of files contain correct information) of microcredit in the $6^{\text {th }}$ largest region of France during seven years.

\subsection{Statistical results}

$34.6 \%$ of microcredits reported in our survey were disbursed to women (Table 1 ). This rate is slightly above the percentage of women company creators in France (28.7\% in 2002), but it is lower than the European rates (respectively $39 \%$ and $30 \%$ in 2004). The percentage of women in the MFIs portfolio is close to the Western European rate but contrasts sharply with the East European (62\%) and North American (59\%) rates, as well as with those in developing countries (84\%).

\footnotetext{
${ }^{9}$ We excluded the data on the few businesses that were created on a family basis.
} 
Table 1.

Entrepreneur characteristics

\begin{tabular}{|c|c|c|c|c|c|c|}
\hline & \multicolumn{2}{|c|}{$\begin{array}{c}\text { Entrepreneurs } \\
\text { (total) }\end{array}$} & \multicolumn{2}{|c|}{$\begin{array}{c}\text { Entrepreneurs } \\
\text { with microcredit }\end{array}$} & \multicolumn{2}{|c|}{$\begin{array}{l}\text { Difference between } \\
\text { Women and Men } \\
\text { (with microcredit) }\end{array}$} \\
\hline & Women & Men & Women & Men & t- Student & Prob. \\
\hline Gender & $28.7 \%$ & $71.3 \%$ & $34.6 \%$ & $65.4 \%$ & & \\
\hline Average age (years) & 38.6 & 38.7 & 36.9 & 37.1 & -0.632 & 0.527 \\
\hline $\begin{array}{l}\text { Nationality } \\
\text { French } \\
\text { Other } \\
\end{array}$ & $\begin{array}{c}92 \% \\
8 \% \\
\end{array}$ & $\begin{array}{l}88 \% \\
12 \% \\
\end{array}$ & $\begin{array}{l}83.9 \% \\
16.2 \% \\
\end{array}$ & $\begin{array}{l}81.1 \% \\
18.9 \% \\
\end{array}$ & 1.917 & $0.055^{*}$ \\
\hline $\begin{array}{l}\text { Level of studies } \\
\text { University } \\
\text { Primary and secondary } \\
\text { school }\end{array}$ & $\begin{array}{l}52.8 \% \\
47.2 \%\end{array}$ & $\begin{array}{c}45.2 \% \\
54.8\end{array}$ & $\begin{array}{l}50 \% \\
50 \%\end{array}$ & $\begin{array}{l}39.2 \% \\
60.8 \%\end{array}$ & 5.091 & $0,000 * * *$ \\
\hline $\begin{array}{l}\text { Occupational status } \\
\text { Active } \\
\text { Unemployed < } 1 \text { year } \\
\text { Long term } \\
\text { unemployed } \\
\text { Inactive }\end{array}$ & $\begin{array}{l}45.5 \% \\
17.1 \% \\
16.1 \% \\
\\
21.3 \% \\
\end{array}$ & $\begin{array}{c}57 \% \\
19.3 \% \\
14 \% \\
9.7 \% \\
\end{array}$ & $\begin{array}{l}13.4 \% \\
19.3 \% \\
11.2 \% \\
56.1 \% \\
\end{array}$ & $\begin{array}{c}17.3 \% \\
21.5 \% \\
10 \% \\
51.2 \% \\
\end{array}$ & $\begin{array}{c}-2.769 \\
-1.408 \\
1.084 \\
\\
3.58 \\
\end{array}$ & $\begin{array}{c}0.006 * * * \\
0.159 \\
0.278 \\
\\
0.000 * * *\end{array}$ \\
\hline $\begin{array}{l}\text { Bank credit } \\
\text { Yes } \\
\text { No } \\
\end{array}$ & $\begin{array}{l}\text { na } \\
\text { na }\end{array}$ & $\begin{array}{l}\text { na } \\
\text { na }\end{array}$ & $\begin{array}{l}20.1 \% \\
79.9 \% \\
\end{array}$ & $\begin{array}{l}23.6 \% \\
76.4 \% \\
\end{array}$ & 5.784 & $0.000 * * *$ \\
\hline $\begin{array}{l}\text { Marital status } \\
\text { Single } \\
\text { Couple }\end{array}$ & $\begin{array}{l}\text { na } \\
\text { na }\end{array}$ & $\begin{array}{l}\text { na } \\
\text { na }\end{array}$ & $\begin{array}{l}60.8 \% \\
39.2 \%\end{array}$ & $\begin{array}{l}42.2 \% \\
57.8 \%\end{array}$ & 9.984 & $0.000 * * *$ \\
\hline $\begin{array}{l}\text { Work experience } \\
\text { Yes } \\
\text { No }\end{array}$ & $\begin{array}{l}\text { na } \\
\text { na }\end{array}$ & $\begin{array}{l}\text { na } \\
\text { na }\end{array}$ & $\begin{array}{l}49.4 \% \\
50.6 \%\end{array}$ & $\begin{array}{l}55 \% \\
45 \%\end{array}$ & -3.016 & $0.003 * * *$ \\
\hline
\end{tabular}

\footnotetext{
*** Differences between men and women are significant at the .01 level.

* Differences between men and women are significant at the .1 level.
}

Sources: Our database and the Sine database of Insee.

As shown in Table 1, of all entrepreneurs, microfinance institutions tend to target relatively more women, young people, foreign born populations, as well as people who are excluded from the labour market. Because of their characteristics, these people are often those who do not have much personal funding, a position that makes access to classic bank credit more difficult. Moreover the number of women who start their business alone is generally higher than for men, who are often helped by their partner (or by a family member). Thus women, who are often single, will a priori have less 
income and fewer guarantees (single source of income, fewer assets) to put forward in order to get external financing. Yet they have a monthly income that is almost equivalent to that of men (the difference is not statistically significant, see Table 2). Moreover, it is interesting to note that a high percentage of single female borrowers have children in their care $(44.4 \%$ of single women, as opposed to only $14.2 \%$ of single men). And yet, it is well known that the risk of poverty is $34 \%$ amongst singleparent families. In our database, almost $80 \%$ of these women receive welfare benefits and $96.7 \%$ of them are excluded from bank funds. Conversely, men who have loans and are in a couple have children more often than women who are in a couple (73.8 \% compared to $66.6 \%)$. Consequently, self employment for single women may be perceived as necessity entrepreneurship ${ }^{10}$, whereas it may be opportunity entrepreneurship for women in a couple.

The male/female difference amongst microcredit beneficiaries does not appear to be significant when compared to the reference population of company creators. In both samples, women have studied more than men but have less work experience in the sphere they are entering. Most of the time they were outside of the workforce (but not on unemployment benefit) before they created their business. Indeed if the difference between women who have benefited from a microcredit and those who have not is not very high (amongst company creators, the percentage of women who went through higher education is of $52.8 \%$ and $50 \%$ amongst microcredit beneficiaries), this difference is much more significant amongst men (45.2\% compared to $39.2 \%)$. Similarly, male company creators are more often in employment ( $57 \%$ compared to $45.5 \%$ for women) whereas women are often beneficiaries of welfare benefits (21.3\%, compared to $9.7 \%$ for men). Amongst microcredit beneficiaries, the gap lessens greatly, leading us to believe that MFIs tend to favour active women and men in consistent poverty. Amongst company creators, 1 in 5 women is on state benefit, compared to 1 in 10 men. Amongst microcredit beneficiaries, this rate is almost the same between men and women (1 in 2). Thus comparatively, MFIs

\footnotetext{
${ }^{10}$ For Allen at al. (2007), necessity entrepreneurship refers to people who start their own business because other employment options are either absent or unsatisfactory. They find that necessity entrepreneurship is much more prevalent among women than men.
} 
fight the battle against poverty and exclusion more for men than for women. There is no indication, however, that this is indeed discrimination by MFIs rather than self-selection (discrimination) by women themselves.

Table 2. Funding characteristics

\begin{tabular}{|c|c|c|c|c|}
\hline & Women & Men & $\begin{array}{l}\text { Difference between } \\
\text { Women and Men } \\
\text { (t statistic) }\end{array}$ & $\begin{array}{l}\text { Probability } \\
\text { for t-statistic }\end{array}$ \\
\hline Loan maturity (months) & 25 & 27 & -2.677 & $0.007 * * *$ \\
\hline Interest rate $(\%)$ & 4.65 & 4.39 & 1.741 & $0.082 *$ \\
\hline $\begin{array}{cl}\text { Beneficiaries in \%: } \\
-\quad \text { Interest free loan } \\
-\quad \text { Own funds } \\
-\quad \text { Loan subsidy } \\
- & \text { Bank loan }\end{array}$ & $\begin{array}{l}56.1 \% \\
37.8 \% \\
24.4 \% \\
20.1 \%\end{array}$ & $\begin{array}{c}61.4 \% \\
41.9 \% \\
23 \% \\
23.6 \%\end{array}$ & $\begin{array}{l}-3.054 \\
-2.339 \\
0.931 \\
-2.351\end{array}$ & $\begin{array}{c}0.002 * * * \\
0.002 * * * \\
0.352 \\
0.019 * *\end{array}$ \\
\hline Average amount of MFIs loan (euros) & 4106 & 5009 & -6.666 & $0.000 * * *$ \\
\hline Total need for funds (euros) & 21859 & 30033 & -3.271 & $0.001 * * *$ \\
\hline Own resources (euros) & 5067 & 8444 & -2.405 & $0.016 * *$ \\
\hline $\begin{array}{l}\text { Average amount of supplementary bank loan } \\
\text { (euros) }\end{array}$ & 9340 & 12812 & -2.421 & $0.016^{* *}$ \\
\hline Losses $(\%)$ & $2.6 \%$ & $3.7 \%$ & -1.7 & $0.089 *$ \\
\hline Monthly available income (euros) & 1147 & 1114 & 0.835 & 0.404 \\
\hline
\end{tabular}

*** Differences between men and women are significant at the .01 level.

** Differences between men and women are significant at the .05 level.

* Differences between men and women are significant at the .1 level.

The total amount of women's projects is on average almost $40 \%$ lower than that of men, which corresponds exactly to the gap between the complementary bank funds of both sexes (Table 2). It is on the own funds level that the gap is the widest (- 67\%). Women meet their need for funds by using relatively more microcredits. As expected, beneficiaries of a micro-loan are two times less likely to have access to bank credit than the average company creator ( $20.1 \%$ of women and $23.6 \%$ of men compared to $45 \%$ and $43 \%$ respectively). It is interesting to note that women have a guarantee fund (FGIF), managed by France Active since 2002, in order to facilitate their access to bank credit. This fund 
guarantees loans between 5,000 and 48,000 euros. It appears to be useful since, in our sample, only $0.17 \%$ of women had a loan higher than this guaranteed limit, compared to $8.3 \%$ of men.

Although women borrow less and over a slightly shorter period, their lending interest rate is on average higher, which can in part be explained by the fact that men benefit more often from interestfree loans. This confirms the results of Coleman (2000) who suggests that higher interest rates are associated with smaller loans and female borrowers.

Yet women, maybe because they are subjected to tighter selection than men, have a much higher repayment rate than men ${ }^{11}$. But a high repayment rate tells us nothing of the difficulties that have to be faced. Women often attach more importance to the credit relationship than to their capacity to generate a decent monthly income, which can jeopardize the business's survival. The credit will have been paid back under the agreed conditions, but the business will have disappeared.

Table 3. Project characteristics

\begin{tabular}{|c|c|c|}
\hline & Women & Men \\
\hline $\begin{array}{l}\text { Legal structure }(\%) \text { : } \\
\begin{array}{rlll}\text { - } & \text { Limited liability company } & & \\
\text { - } & \text { Sole ownership } \\
\text { - } & \text { Private limited company under sole } \\
& \text { ownership }\end{array}\end{array}$ & $\begin{array}{c}29 \\
59.3 \\
11.7\end{array}$ & $\begin{array}{l}43.7 \\
43.7 \\
12.6\end{array}$ \\
\hline $\begin{array}{cl}\text { Business } & \text { sector }(\%): \\
- & \text { Retail trade } \\
- & \text { Personal service } \\
\text { - } & \text { Services for firms } \\
\text { - } & \text { Building industry } \\
\text { - } & \text { Farming } \\
\text { - } & \text { Catering } \\
\text { - } & \text { Craft industry }\end{array}$ & $\begin{array}{c}35.8 \\
40.8 \\
6.6 \\
1.2 \\
2.4 \\
7.8 \\
5.4\end{array}$ & $\begin{array}{c}30.2 \\
25.4 \\
7.6 \\
16.9 \\
6.4 \\
7.5 \\
5.9\end{array}$ \\
\hline
\end{tabular}

In accordance with other surveys of company creators in France, but in other industrialized countries also, more than three-quarters of women are to be found in the retail trade sector or among service providers for private individuals (Table 3). Men are found in many more sectors, including the construction sector, agriculture, or service providers for businesses. Despite the fact that selfemployment has often been presented as an opportunity for women, particularly in terms of autonomy,

\footnotetext{
${ }^{11}$ This result confirms that women are generally better credit risks in microfinance than men (D'Espallier et al., 2010).
} 
personal development and professional progress, studies confirm that women reproduce a certain sectoral segregation. According to Hugues (1999), because they do not have enough capital and contacts, and because they are more involved in domestic work and in their children's education, women work in "peripheral economic niches", such as retail trade or in personal service. These highly competitive sectors with low barriers to entry have low profit margins. In contrast, men's work is more diversified, in retail trade, services to businesses, in the construction sector or in transport.

Women choose legal structures that are more adaptable and need lower personal funds. Almost $60 \%$ of them thus opt for a sole ownership, where the borrower is liable for his/her debts on his/her personal assets, as opposed to $43.7 \%$ of men. The same proportion of men choose a limited liability company ( $43.7 \%$ of all projects, against $29 \%$ for women). The legal status that is chosen is generally correlated with the business sector.

When it comes down to it, whether one is studying microcredit in developing countries or in rich countries, similar observations can be made: women are limited to activities considered to be feminine (personal services, retail trade), to poorly capitalistic activities that generate little profit. One explanation is that women start their business with a lower level of start-up capitalization. This is one of the reasons why they choose a legal structure and a type of activity that require little investment in capital but that will not enable them to generate a significant income. The univariate analysis of male and female microcredit borrowers revealed several significant differences in firm and owner characteristics. Notably, we found a significantly lower amount of microcredit for women compared with men. We will now carry out a multivariate analysis in order to explain these male/female differences.

\subsection{Multivariate Analysis}


Multivariate analysis will help clarify the role of gender in the amount of microcredit, taking into account some control variables, as project or owner characteristics. As we have seen, the impact of gender on the ability to borrow money can be linked to two types of consideration. The first is due to an indirect effect: women borrow less because they have fewer personal assets, less experience, and because they choose activities that require less investment (financial and personal). Therefore, the lower value of loans disbursed to women results from a combination of demand and supply factors explained by the borrower or project particularities. The second effect is more direct: the funding differences cannot be attributed to these previous factors, in which case there is a "gender effect" (Verheul and Thurik, 2000). Discrimination in the credit market occurs when lenders' decisions on loan applications are influenced by personal characteristics, such as gender, that are not relevant to the transaction (Muravyev et al., 2009). In order to find a gender effect, we have to control for the different factors related to borrower characteristics, to project characteristics and to fund characteristics $^{12}$.

The estimated equation takes the following form:

$$
Y_{i}=\alpha+\beta \operatorname{Woman}_{i}+X_{i} \chi+\varepsilon_{i}
$$

The "Woman" variable is a dummy variable that specifies whether the borrower is a woman. If the differences in the microcredit's amount can be explained by borrower characteristics (other than gender) or by project characteristics (its size, business sector, supplementary funds), "Woman's" $\beta$ coefficient should not be statistically significant.

\footnotetext{
${ }^{12}$ For the methodology, see for example Cole and Mehran (2009), Muravyev et al. (2009), or Belluci et al. (2010).
} 
$\mathrm{X}$ is a vector that captures the characteristics of the borrowers and of the project (ie the supply and demand factors) and $\varepsilon$ is the error term. The borrower characteristics taken into account are age, experience, ethnic background, level of studies, monthly income level and occupational status (employee, corporate manager, unemployed for less or more than one year, beneficiary of welfare benefits, other). We also introduced the squared age so that any potential nonlinearities linked to age could be taken into account. The project characteristics are its amount, the business sector and the type of project (creation, buyout or development of a business). Lastly, fund characteristics are the availability and amount of supplementary funds (own funds, bank credits, financial assistance).

We estimate the microcredit supply's determinants by using an OLS regression with fixed effects to take into account the structural specifics of the different microfinance institutions we studied. This model allows for heteroskedasticity of errors by MFIs. We didn't find any collinearity between the explanatory variables ${ }^{13}$. The results are shown in Table 4, the description of the variables can be found in annex 1 . Only the variables significantly different from zero are presented.

The multivariate analysis reveals that the amount of the microcredit increases with the age of the borrower, his/her level of studies and if the borrower is a man. Social and professional status is also important. The loan will be of a greater amount if the borrower is an employee or already a corporate manager at the time of the loan, whereas the loan will be of a smaller amount if the borrower receives welfare benefits. The other significant variables have to do with the project: some sectors (such as cafés, hotels, restaurants, or the construction sector), or legal structures (private limited company under sole ownership) require higher microcredit funds. The amount of the micro loan will be greater if the project is of greater importance (this amount will also be correlated to supplementary funds, personal assets or bank loan), if it benefits from financial assistance (subsidy, interest-free loan) and if it funds the creation of a business (i.e. if it does not buyout or plan to develop an already existing business).

\footnotetext{
${ }^{13}$ The correlation between explanatory variables is very low and the variance inflation factors (VIFs) is low (=1.2).
} 
The regression was also done separately for men and women in order to evaluate whether the amount of the loan was determined by different reasons depending on the borrower's sex. The first result is that the borrower's personal characteristics are of little significance for women, whereas age, level of studies and marital status are key factors for men. Another interesting result is that the micro loan's amount will be directly correlated to the amount of the financial assistance (subsidy) that will have been obtained by women, yet for men, this variable is never significant ${ }^{14}$. This seems to confirm the usefulness of help directed specifically at women and therefore, implicitly, that women are penalized in their access to funds.

14 Even if access to subsidies does not vary statistically depending on gender (cf. table 2). 


\section{Table 4. Fixed-effects (within) regression: key factors when determining the amount of the micro-loans}

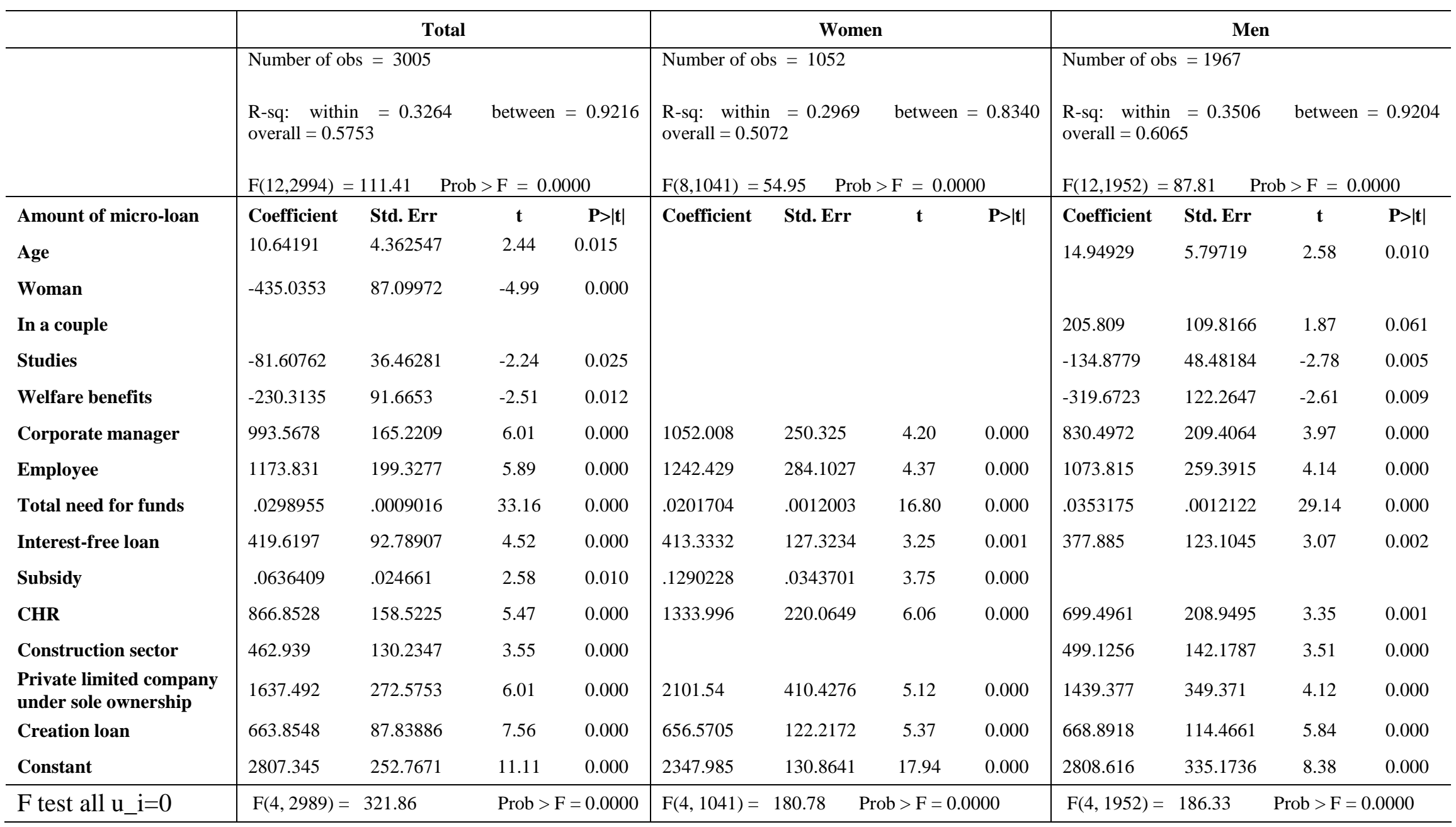


Because the gender variable is significant in the general equation, and despite the fact that borrower characteristics and his/her project and financial plan are taken into account, it seems to confirm the existence of discrimination against women on the part of microfinance institutions. This result, however, is based on a strong hypothesis: that all of the other characteristics of the individual and of the project have indeed been taken into account. As in previous studies, gender discrimination is difficult to demonstrate empirically due the existence of several factors which make the isolation of gender difficult. Empirical studies are possibly subjected to a "missing variable error". However, our research is based on credit files given to us by microcredit institutions. So we have included in our estimations all the objective information that these institutions had. The data of our econometric estimates are therefore relatively exhaustive. More subjective information could not be taken into account however, such as the way a banker perceives his/her client, which often results from a face to face meeting. Indeed, during an interview, a banker can assess his/her client's ease and the size of his/her social capital (is he/she part of a charity network, what is the level of education of those around him, does he/she know other corporate managers...).

In order to confirm our econometric results and test the hypothesis of missing variable error (that can lead to biased estimates and inappropriate conclusion about a gender effect), we have estimated the same equation to determine the amount of the supplementary bank credit (from classical banking institutions) (Table 5). This estimate can be used for comparison (control group). We estimated the key factors that determine the amount of the bank credit that supplements the micro-loan by using the same explanatory variables, in order to determine whether the gender variable is still significant. 
Table 5. bank credit

Fixed-effects (within) regression: key factors when determining the amount of the

\begin{tabular}{lllcccc}
\hline Amount of bank credit & Coefficient & Std. Err & $\mathbf{t}$ & \multicolumn{1}{c}{$\mathbf{P}|\mathbf{t}|$} & \multicolumn{2}{c}{ [95\% Conf. Interval] } \\
\hline Woman & 490.5896 & 684.2657 & 0.72 & 0.473 & -851.0766 & 1832.256 \\
\hline Employee & 5151.505 & 1497.375 & 3.44 & 0.001 & 2215.544 & 8087.467 \\
\hline $\begin{array}{l}\text { Amount of personal } \\
\text { assets }\end{array}$ & 1.432151 & .0208851 & 68.57 & 0.000 & 1.391201 & 1.473102 \\
\hline Subsidy & -.3942381 & .200375 & -1.97 & 0.049 & -.787121 & -.0013551 \\
\hline CHR & 4563.054 & 1283.631 & 3.55 & 0.000 & 2046.189 & 7079.919 \\
\hline Trade & 1245.48 & 704.3989 & 1.77 & 0.077 & -135.662 & 2626.622 \\
\hline limited liability company & 6712.486 & 1442.23 & 4.65 & 0.000 & 3884.649 & 9540.322 \\
\hline Buyout loan & 3393.275 & 752.204 & 4.51 & 0.000 & 1918.4 & 4868.151 \\
\hline Constant & -1688.588 & 558.2627 & -3.02 & 0.003 & -2783.195 & -593.9805 \\
\hline
\end{tabular}

$F(8,3064)=641.44 \quad$ Prob $>F=0.0000$

F test that all $u_{-} i=0: \quad F(4,3064)=6.51 \quad$ Prob $>F=0.0002$

A noteworthy finding is that the gender variable is not significant in determining the amount of bank loans. This indicates that bank lenders do not discriminate against women in providing access to a Ioan when we control for project and owner characteristics. Of all the characteristics of the borrower, this loan depends only on the borrower's social status (regularity of monthly income due to working as an employee) and on his/her personal assets. Moreover, the bank loan will be higher for buyouts, for limited liability companies, and in the retail trade and the café hotel and restaurant sectors. Moreover, financial assistance becomes a substitute for bank loans, which thus turns into supplementary funding.

Finally, we created representative sub-samples. Another way to deal with the challenge of disentangling the effect of gender from the effects of variables associated with gender is to use a "matching technique" (Fabowale et al. 1995). One factor that may explain why women experience greater difficulty in obtaining credit on average is their lower level of personal assets. We first study a 
representative sub-sample ${ }^{15}$, based on an identical amount of personal assets in the men's group and in the women's group (this amount is 13,800 euros). Women's need for loans is slightly lower than men's (with a total project of 45,373 euros for women, 47,622 for men, that is $-4.5 \%$ ) whereas the amount of the microcredit is lower by $10 \%(6,125$ euros compared to 6,781$)$. To compensate for this, women borrow a little more from banks (higher amount and indebtedness rate) ${ }^{16}$. A second representative subgroup, made up of 2,152 men and 952 women, was created on the basis of a project with an identical average amount (25,400 euros). Again, the amount of microcredits obtained by women is lower than men's by $9 \%(10,570$ euros compared to 11,591 , bearing in mind that the difference becomes statistically significant at $1 \%$ ). Differences in personal assets (on average $-2.2 \%$ ) or in monthly income are not significant. In terms of supplementary funds, women obtain more bank loans (+ 9.6\%) and a little more financial assistance (+ 3.3\%). In the latter case, however, the difference is not significant.

\section{Conclusion}

This article examines the loan portfolio of 12 institutions of microfinance and compares access to microcredit for men and women. This leads to three results.

Firstly, whether in developing countries or in industrialized countries, women face the same difficulties in their projects to create their own business. Some of these difficulties are linked to women as individuals (their skills, their experience, their self-confidence), some are family-related (couple relationships, children), but there are also economic and financial difficulties: poor access to outside funds, activities that generate little income, weight of domestic chores (Johnson 2000).

15 Of borrowers with non-zero personal assets.

16 The gap is smaller between men and women for borrowers without own funds. Within this group, women have projects that are lower than men's by $10.9 \%$ and their microcredit amount is lower by $13 \%$. 
Secondly, microfinance can support female entrepreneurship by providing easier access to finance and technical assistance. However, our study reveals that despite a great potential to meet women's financing needs, the lending rate of IMFs in France, as in Europe, remains low. Moreover, it appears from our study that women are somewhat more penalized that men in their access to microcredit (price and non-price terms of loan contracts), and that personal differences or differences in projects cannot, per se, explain such a gap. For an identical project, women tend to start their business with fewer microcredit resources than men do, and the interest rate charged on their loan is higher.

Thirdly, microfinance institutions appears more interested, as traditional banking institutions, by the credit relationship and the likelihood of repayment of the loan rather by the type of business that is being financed (business sector, legal structure...). In other words, MFIs do not really promote women's enterprise beyond credit and don't prevent women to stay in traditional activities. Almost $30 \%$ of MFls in Europe implement programmes without support services, and $96 \%$ do not have a policy with respect to women (Underwood, 2007).

These results may have some implications for the MFIs or Government policies. MFIs may not be considered in the same way as other finance organizations, they also have to have a role of counsel and support. More than the supply of funds, MFI can also play an important part in informing and guiding women towards more profitable projects. They must have a team of professionals aware of the constraints facing women and their attitudes towards debt or entrepreneurship. Microfinance must be adapted to women with regard to collaterals, bonds or the repayment period (which could be more flexible). The MFIs can also organize group coaching or promoting in order to improve women's selfconfidence. In Western Europe, lenders have adopted a "gender neutral" approach to service provision, but at the same time, they are aware that women face gender-specific challenges. Although $59 \%$ of microlenders did not think women face particular barriers when seeking microcredit, $69 \%$ of them felt that specific measures are needed to improve women's success in accessing micro loans (Underwood, 
2007). The measures suggested by microlenders are notably pre-loan assistance with business planning and having female loan officers. They also suggested special loan products. Hayen et al. (2007) propose also to establish locally available networking opportunities for women business owners and to foster the exposure of female entrepreneurs in the media17.

Governments should also consider taking special measures for women. Mechanisms that enable women to accumulate more personal assets and to have access to larger loans should be considered, as studies have shown that these will enable the funding of more profitable and viable projects. The undercapitalization of new firms has a long term implication for business performance. Governments can also offer services that take into account the situation of women, such as maintaining welfare benefits or child care arrangements, after business creation. Lastly, Governments should promote entrepreneurship skills such as risk taking or creativity (Lämmermann, Underwood, 2007).

17 see also Eurochambres 2006. 


\section{References}

Allen I.E., Langowitz N., Minniti M. (2007). 2006 Report on Women and Entrepreneurship. Global Entrepreneurship Monitor.

Anderson S., Carter S., Shaw E. (2001). Women's Business Ownership: A Review of the Academic, Popular and Internet Literature. Small Business Service Research Report: RR002/01, August.

Barbato R., DeMartino R. (2003). Differences between women and men MBA entrepreneurs: exploring family flexibility and wealth creation as career motivators. Journal of Business Venturing, 18(6), November, 815-832.

Bellucci A., Borisov A., Zazzaro A. (2010). Does gender matter in bank-firm relationships? Evidence from small business lending. Journal of business Banking and Finance 34, 2968-2984.

Bird B., Brush C. (2002). A Gendered Perspective on Organizational Creation. Entrepreneurship, Theory and Practice, 26(3), 41-65.

Boden R.J., Nucci A. (2000). On the Survival Prospect of Men's and Women's New Business Ventures. Journal of Business Venturing, 15, 347-362.

Brush, C., Carter, N.M., Gatewood, E.J., Greene, P.G., Hart, M. (Eds.). (2006). Growth-oriented women entrepreneurs and their businesses: A global research perspective. Cheltenham, U.K.: Elgar.

Buttner E.H., Rosen B. (1988). Bank loan officers' perceptions of the characteristics of men, women, and successful entrepreneurs. Journal of Business Venturing, 3(3), Summer, 249-258.

Carter S., Shaw E. (2006). Women's Business Ownership: recent research and Policy Developments. Report to the Small Business Service, November.

Carter S, Lam W., Shaw E., Wilson F. (2007). Gender, Entrepreneurship, and Bank Lending, the Criteria and Processes used by Bank Loan Officers in Assessing Applications. Entrepreneurship Theory \& Practice, 31(3), May, 427-444.

Cheston S. (2007). Just the Facts, Ma'am': Gender Stories from unexpected Sources with Morals for Microfinance. In ADA Dialogue "Microfinance and Gender: New contributions to an Old Issue ", $n^{\circ}$ 37, May, 13-25. 
Cole R.A., Mehran H. (2009). Gender and the availability of credit to privately held firms: Evidence from the surveys of small business finances. Staff Report, 383, Federal Reserve Bank of New York.

Coleman S. (2000). Access to Capital and Terms of Credit: A comparison of Men- and Women- Owned Small Businesses. Journal of Small Business Management, 38(3), July, 37-52.

Croson R., Gneezy U. (2009). Gender Differences in Preferences. Journal of Economic Literature, 47(2), 127.

Danes S.M., Stafford K., J.T.-C. Loy (2007). Family Business Performance: The effects of gender and management. Journal of Business Research, 60(10), October, 1058-1069.

De Bruin A., Brush C.G., Welter F. (2007). Advancing a Framework for Coherent Research on Women's Entrepreneurship. Entrepreneurship, Theory and Practice, 31(3), May, 323-339.

D'espallier B., Guérin I. (2010). Women and Repayment in Microfinance: A global Analysis. World Development, article in press. doi: 1016/j.worlddev.2010.10.008.

Eurochambres (2006). How to Overcome Stereotypes in Employment, Chambers' tools and best practices. Eurochambres Women Network; February.

European Commission (2006). Gender inequalities in the risks of poverty and social exclusion for disadvantaged groups in thirty European countries. Expert Group on Gender, Social Inclusion and Employment, July.

European Commission (2007). Report on equality between men and women, February.

Fabowale L., Orser B., Riding A. (1995). Gender, Structural Factors, and Credit Terms between Canadian Small Businesses and Financial Institutions. Entrepreneurship Theory \& Practice, Summer, 19(4), 41-65.

Fay M. (1993). Gender bias and the availability of business loans. Journal of Business Venturing, 8(4), July, 363-376.

Fernando J. (ed.) (2006). Perils and Prospects of Microfinance, London, Routledge.

Goetz A, Gupta R.S. (1996). Who Takes the Credit? Gender, Power and Control Over Loan Use in Rural Credit Programs in Bangladesh. World Development, 24(1), 45-63. 
Guérin I., Palier J. (2006). Microfinance and the Empowerment of Women: Will the Silent Revolution Take Place. Finance and the Common Good, 25, Autumn, 76-82.

Hughes, K. D. (1999). Gender and Self-Employment in Canada: Assessing Trends and Policy Issues, Ottawa: Canadian Policy Research Networks, CPRN W/04.

Johnsen G.J., McMahon R.G.P. (2005). Owner-manager Gender, Financial Performance and Business growth amongst SMEs from Australia's Business Longitudinal Survey. International Small Business Journal, 23(2), 115-142.

Johnson S. (2000). Gender Impact assessment in microfinance and microenterprise: why and how. Development in practice, 10(1), February. 89-93.

Johnson S. (2005). Gender relations, Empowerment and Microcredit: Moving on from a Lost Decade, The European Journal of Development Research, 17(2), June, 224-248.

Hayen D., Lahn S., Lämmermann S., Guichandut P., Underwood T., Unterberg M. (2007). Fostering gender equality: Meeting the Entrepreneurship \& Microfinance Challenge, European Report.

Lämmermann S., Underwood T. (2007). Fostering gender equality: Meeting the Entrepreneurship \& Microfinance Challenge, Country Report: France, July.

Langowitz N., Minniti M. (2007). The Entrepreneurial Propensity of Women. Entrepreneurship: Theory and Practice, 31(3), May, 341-364.

Mayoux L. (2007). Not only Reaching, but also Empowering Women: Ways Forward for the Next Microfinance Decade. In ADA Dialogue "Microfinance and Gender: New contributions to an Old Issue", 37, May, 35-60.

Marlow S., Patton D. (2005). All Credit to Men? Entrepreneurship, Finance and Gender. Entrepreneurship, Theory and Practice, 29(6), 717-735.

Muravyev A., Talavera O., Schäfer D. (2009). Entrepreneurs' gender and financial constraints: Evidence from international data. Journal of Comparative Economics, 37(2), 270-286.

Riding A., Swift C. (1990). Women business owners and terms of credit: some empirical findings of the Canadian experience. Journal of Business Venturing, 5(5), September, 327-340. 
Robb A., Wolken J. (2002). Firm, Owner, and Financing Characteristics: Differences between Female- and Male-owned Small Businesses. Finance and Economics Discussion Series, The Federal Reserve Boards, 18, April.

Scalera D., Zazzaro A. (2001). Group reputation and persistent (or permanent) discrimination in credit markets. Journal of multinational Financial Management, 11(4-5), December, 483-496.

Underwood T. (2006). Women and Microlending in Western Europe. EMN Working Paper 2, April.

Verheul, Thurik (2000). Start-Up Capital : Differences between male and Female Enntrepreneurs 'Does Gender Matter ?', ERIM Report Series Research in Management, March.

Watson J. (2002), Comparing the Performance of Male- and Female- Controlled Businesses: Relating Outputs to Inputs, Entrepreneurship Theory and Practice", 26(3), Spring, 91-100.

Watson J., Robinson S. (2003). Adjusting for risk in comparing the performance of male-and female controlled SMEs. Journal of Business Venturing, 18(6), 773-788. 
Annex 1: Descriptive statistics for dependant and independent variables

Number of observations $=3866 \quad$ Period $=2000-2006$

Dummy variables

\begin{tabular}{|c|c|c|}
\hline Variable & Mean & Standard Errors \\
\hline \multicolumn{3}{|l|}{ Bank loan } \\
\hline Yes $=1$ Non $=0$ & 0.297 & 0.44 \\
\hline \multicolumn{3}{|l|}{ Sex } \\
\hline Woman $=1$ Man $=0$ & 0.346 & 0.476 \\
\hline \multicolumn{3}{|l|}{ Ethnic background } \\
\hline French $=1$ Other $=0$ & 0.821 & 0.383 \\
\hline \multicolumn{3}{|l|}{ Marital situation } \\
\hline single, widow, divorced $=1$ & 0.488 & 0.499 \\
\hline \multicolumn{3}{|l|}{ Married, in a couple $=0$} \\
\hline \multicolumn{3}{|l|}{ Social status } \\
\hline Welfare benefits $=1$ if not $=0$ & 0.346 & 0.476 \\
\hline Unemployed $(<1$ year $)=1$ if not $=0$ & 0.207 & 0.405 \\
\hline Unemployed (> 1 year) if not $=0$ & 0.104 & 0.305 \\
\hline Corporate manager $=1$ if not $=0$ & 0.091 & 0.288 \\
\hline Employee $=1$ if not $=0$ & 0.068 & 0.252 \\
\hline Other & 0.05 & 0.218 \\
\hline \multicolumn{3}{|l|}{ Own funds } \\
\hline $\mathrm{Yes}=1 \quad \mathrm{No}=0$ & 0.413 & 0.492 \\
\hline \multicolumn{3}{|l|}{ Experience } \\
\hline Yes $=1 \quad \mathrm{No}=0$ & 0.615 & 0.499 \\
\hline \multicolumn{3}{|l|}{ Purpose of the loan } \\
\hline New business $=1$ if not $=0$ & 0.578 & 0.494 \\
\hline Repurchase $=1$ if not $=0$ & 0.276 & 0.447 \\
\hline Expansion $=1$ if not $=0$ & 0.145 & 0.352 \\
\hline \multicolumn{3}{|l|}{ Activity } \\
\hline Craft industry $=1$ if not $=0$ & 0.057 & 0.232 \\
\hline Services for firms $=1$ if not $=0$ & 0.073 & 0.26 \\
\hline Services for private households $=1$ if not $=0$ & 0.308 & 0.461 \\
\hline Retail trade $=1$ if not $=0$ & 0.321 & 0.467 \\
\hline Building industry $=1$ if not $=0$ & 0.114 & 0.317 \\
\hline Farming $=1$ if not $=0$ & 0.05 & 0.218 \\
\hline Catering $=1$ if not $=0$ & 0.077 & 0.265 \\
\hline \multicolumn{3}{|l|}{ Level of education } \\
\hline University (Master's degree - $\mathrm{PhD})=1$ & 3.34 & 1.136 \\
\hline \multicolumn{3}{|l|}{ University (Bachelor's degree $)=2$} \\
\hline \multicolumn{3}{|l|}{ Baccalaureate $=3$} \\
\hline \multicolumn{3}{|l|}{ Secondary school $=4$} \\
\hline Junior school $=5$ & & \\
\hline
\end{tabular}


Quantitative variables

\begin{tabular}{lcc}
\hline \multicolumn{1}{c}{ Variable } & Average & Gap \\
\hline Age (years) & 37 & $18-70$ \\
\hline Microcredit amount (euro) & 4801 & $100-38000$ \\
\hline Bank credit amount (euro) & 12689 & $0-785000$ \\
\hline Total need for funds (euro) & 28719 & $100-1516868$ \\
\hline Personal assets amount (euro) & 7581 & $0-1417776$ \\
\hline Monthly income (euro) & 1127 & $35-9100$ \\
\hline Loan's maturity (months) & 26.4 & $1-92$ \\
\hline Interest rate (\%) & 4.2 & $0-23$ \\
\hline
\end{tabular}

